\title{
WHEN IS AN ILEAL CONDUIT INDICATED IN THE SPINAL CORD INJURED PATIENT?
}

\author{
By ROBERT H. HACKLER, M.D. \\ McGuire VA Hospital, Associate Professor of Urology, Medical College of Virginia, \\ U.S.A.
}

Abstract. Ileal loop diversion is only considered for persistent or progressive hydronephrosis (failed conservative treatment directed at the bladder). This conservative approach is based on a comparison of our ongoing prospective mortality study on 470 paraplegics plus $\mathrm{I} 75$ spinal cord patients that have survived at least 20 years $v$. an updated literature review of ileal conduits performed for benign disease.

Key words: Ileal conduit.

INDICATIONS for ileal loop diversion in the paraplegic brings up a controversial subject. The complete answer may never be known, but by utilising what information that is available, I will try to justify a conservative approach concerning indications.

The two most common causes of renal failure are amyloidosis and irreversible vesico-ureteral reflux. On evaluating our autopsies expiring secondary to renal failure, over 80 per cent had amyloidosis and/or vesico-ureteral reflux (Hackler, 1973). Chronic pyelonephritis is evident in most long-term paraplegics on postmortem examination: however, I feel it is the exception for uncomplicated pyelonephritis to lead to renal insufficiency. It is usually associated with amyloidosis, nephrosclerosis, or persisent reflux. Hydronephrosis should not be a major cause of renal death. In a recent study at our hospital on 175 spinal cord injured patients admitted during the past 2 years, having survived at least 20 years post injury (average $24 \cdot 2$ years), I4 per cent or 24 patients had some degree of hydronephrosis (Grades 2, 3, 4) at the time of admission (see Table I) (Hackler, I977). Hydronephrosis was corrected by measures directed at the bladder level in 20 of these patients, for only four have undergone ileal loop diversion. This hydronephrosis can be usually reversed depending on the aetiology. If due to high residual urine (external appliance patient), Foley catheter drainage may suffice. If this significant residual is secondary to excessive resistance in the area of the membranous urethra, external sphincterotomy may rehabilitate the bladder at a later date. Hydronephrosis secondary to a contracted, hyperreflexic bladder may be alleviated by frequent bladder irrigations with an antiseptic solution if the spasticity is due to severe cystitis. Hyperreflexic bladder due to persistent cord impulses (intact sacral reflex arc) may be corrected by anti-spasmoic medication or some type of nerve interruption procedure (Hutch, 1957; Misak et al., 1962; Manfredi et al., I968; Rockswold et al., 1973).

What is the long-term status of the kidneys following ileal diversion? It is difficult to obtain significant data on ileal loop diversion performed for benign disease in relatively young individuals. Few articles are addressed specifically to spinal cord injured patients and many do not distinguish results between benign and malignant disease. The main drawback is follow-up for most reports only average 4 to 5 years. One must evaluate ileal loop diversion for benign disease in children in order to obtain any insight concerning kidney status, mortality, and 
TABLE I

Retrospective study (Hackler, I977)

\begin{tabular}{|c|c|c|c|c|}
\hline \multirow[t]{3}{*}{ I.V.P. } & \multicolumn{3}{|c|}{ Renal unit status } & \\
\hline & $\overline{\text { Overall }}$ & 'Texas' & Foley & \\
\hline & No. $(\%)$ & No. $(\%)$ & $\begin{array}{c}\text { Total } \\
\text { No. }(\%)\end{array}$ & $\begin{array}{l}\text { Reflux } \\
\text { No. }\end{array}$ \\
\hline Normal & $205(59)$ & I $28(66)$ & $77(5 \mathrm{I})$ & 12 \\
\hline I & $80(23)$ & $44(23)$ & $36(24)$ & IO \\
\hline $2-3$ & 42 & I4 & 28 & 7 \\
\hline 4 & 7 & 6 & I & 0 \\
\hline Non-function & 4 & 0 & 4 & 0 \\
\hline Nephrectomy & 9 & 3 & 6 & 5 \\
\hline
\end{tabular}

complications. I recently evaluated ileal loop diversion in children in 13 articles. These articles were selected because they have results concerning the condition of the kidneys before and after ileal loop diversion. In I I articles with an average follow-up of only $4 \cdot 1$ years, the total number of renal units evaluated were 1422 (Fig. I). In the 6I6 renal units that were normal preoperatively, 22 per cent

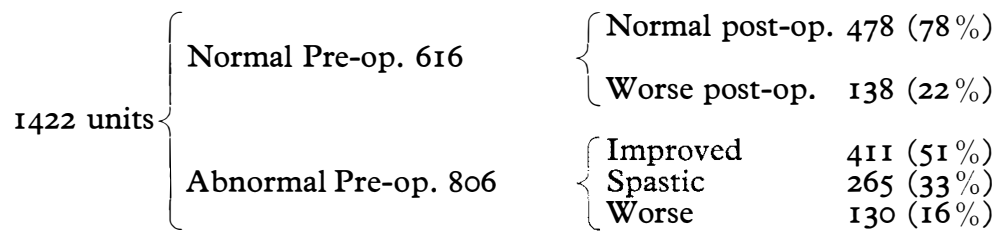

Average follow-up $-4 \cdot \mathrm{I}$ years

FIG. I

IVP status post-ileal conduit.

deteriorated following diversion. There have been some recent articles with longer follow-up. Middleton and Hendren reported on 78 renal units with at least a 7 -year follow-up. Of the 26 renal units that were normal preoperatively, 77 per cent deteriorated following diversion. There were two reports in 1975 with a follow-up of over Io years by Shapiro et al. (1975) and Schwarz et al. (1975). In their patients, 39 per cent of the normal renal units preoperatively deteriorated following diversion (Fig. 2).

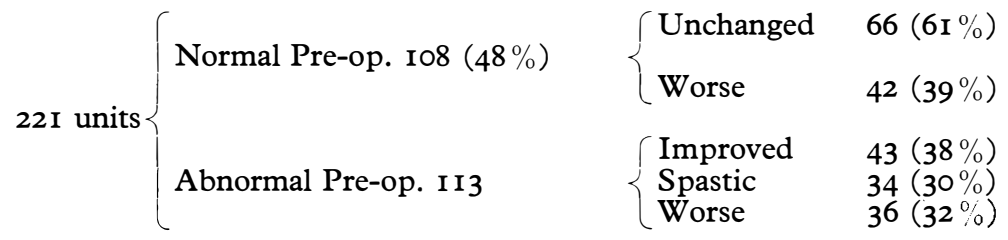

At least Io-year follow-up (av. I I 2 years)

FIG. 2

IVP status post-ileal conduit. 
These figures can be compared to our prospective study on the Vietnam War paraplegics who are now over Io years post-injury (Donnelly et al., I972). Of the Io0 original patients, ten are dead, but only one from renal cause. This patient expired I year following ileal diversion (performed elsewhere) secondary to multiple renal abscesses and septicaemia. Seventy-six of the 90 living Vietnam patients have had intravenous urograms during the past year. Twenty-eight per cent have some renal damage as compared to 39 per cent of the loop patients (Table II). These figures may be significant $(p=0.07)$. However, only one paraplegic had greater than Grade I (chronic pyelonephritis) urogram changes. The loop children could not be evaluated as to urogram status.

Even though ileal loop patients currently can be evaluated up to Io years, we have data on the status of the spinal cord injured patient on a prospective basis up to 25 years (Hutch \& Bunts, I95I; Lord et al., I956; Hoffman et al., I96I; Wadewitz et al., I968; Donnelly et al., I972). The corrected mortality rate some 25 years post injury on 270 patients was 49 per cent (Table III) (Hackler, I977). If the 23 patients lost to follow-up are included, the 56 per cent have expired. Renal disease accounted for 43 per cent of the deaths and 2I per cent of the entire group. The follow-up on kidney status is now 27.5 years. Of the 127 patients still alive, 76 have had intravenous urograms during the past $\mathrm{I} \cdot 5$ years (Table IV). Fortytwo per cent have some degree of urogram deterioration after 25 years. This correlates well with our retrospective study after 24.2 years where 4I per cent had renal changes (Table I). Thus, renal status on a projected percentage basis at

TABLE II

IVP status (units)-Io years

\begin{tabular}{|c|c|c|c|}
\hline & \multirow[t]{3}{*}{ Normal } & \multicolumn{2}{|c|}{ Deteriorated } \\
\hline & & \multirow{2}{*}{ Overall } & IVP grade \\
\hline & & & I 2334 \\
\hline Ileal loop* & I08 (pre-op) & $42(39 \%)$ & --- \\
\hline Paraplegic & 152 & $\begin{array}{c}43(28 \%) \\
p=0.07\end{array}$ & $4^{2}--I$ \\
\hline
\end{tabular}

* Schwarz and Jeffs (1975) F. Urol., I14, 285. Shapiro, Lebowitz, and Colodny (1975) $\mathcal{F}$. Urol., 1 14, 289.

TABLE III

25-year prospective renal status for 247 paraplegics

(a) $\mathrm{I} 20$ dead $(49 \%)$

5 I renal deaths $(2 \mathrm{I} \%)$

(b) I27 living

[76 with recent urograms (I 48 units)]

normal- $58 \%$; abnormal- $42 \%$

(c) Projected percentage renal status 21 \% -renal deaths; $42 \%$-abnormal urograms 
TABLE IV

IVP unit status $-27 \cdot 5$ years for 76 patients

\begin{tabular}{cc}
\hline $\begin{array}{c}\text { Grade } \\
\text { Normal }\end{array}$ & $86(58 \%)$ \\
\hline I & 40 \\
2 & I0 \\
3 & 2 \\
4 & 4 \\
Neph. & 4 \\
Azotemia & 2 \\
\hline
\end{tabular}

least 25 years post-injury reveals that 2 I per cent will be dead from renal cause and another 42 per cent will not possess normal upper urinary tracts (Table III). This data may be of use many years hence when it can be compared to a significant number of ileal loops followed for 25 years.

There is little question that a significant complication rate is associated with ileal loop diversion. In most series, greater than 60 per cent of patients will need additional surgery because of complications. The complication rate is decreasing in recent years due to accumulative experience and expertise in technique. Mortality rates following diversion will not be discussed, for in these rather young spinal cord injured patients, it should be extremely low and less than I per cent.

With this information in mind, I feel the only indication for ileal diversion is irreversible hydronephrosis. Besides the significant late complication rate, there appears to be a greater incidence of renal deterioration in the ileal conduit group. Though of questionable significance at the Io-year level, I firmly believe the difference will be significant after 20 to 25 years.

Conversly, the properly selected paraplegic having persistent or progressing hydronephrosis after attempting long-term conservative measures directed at the bladder level will benefit from ileal loop diversion (Figs. I and 2) (Koziol et al., 1975). In fact, those that never recommend this operation may be condemning the patient to subsequent permanent nephrostomies. At this time the major ileal loop evaluation drawback is lack of long-term follow-up. There will be many years before enough conduits can have 20 to 25-year evaluations. Certainly, ureterosigmoidostomy is contra-indicated in these patients due to paralysis of the anal sphincter. Sigmoid loop conduit is an attractive consideration because the ureters can be anastomosed in such a manner as to prevent reflux. However, reluctance to recommend this procedure in the long-term paraplegic is based on the surgical observation that all of these patients have large, thin-wall, adynamic, sigmoid segments probably due to chronic constipation.

\section{Conclusion}

Ileal loop diversion (ureteroileostomy) is only considered for persistent or progressing hydronephrosis (failed conservative treatment directed at the bladder). An attempt to justify this approach was made by comparing the renal status of the non-diverted paraplegic at Io years $v$. a Io-year literature review of ileal conduits performed for benign disease. In the Ioo paraplegics (prospective), 28 per cent of 
renal units deteriorated, but only one unit more than grade I (chronic pyelonephritis). Thirty-nine per cent of the ileal loop renal units deteriorated after Io years. Though not conclusive, it appears that long-term ileal loop patients may have more renal damage. Therefore, until further data is available, we will remain conservative in recommending uretero-ileostomy in these patients.

\section{RÉSUMÉ}

On ne considère le détournement de l'anse iliaque (l'urétéroiléostomie) que pour l'hydronéphrose qui persiste ou qui empire (traitement prudent qui vise la vessie et qui est sans succès). Une tentative pour justifier cette façon de procéder a été faite en comparant l'état rénal du paraplégique à dix ans dont l'anse iliaque n'a pas été détournée contre une revue des publications, au cours d'une période de dix ans, consacrées aux conduits iliaques qui ont été opérés pour les maladies bénines. Sur les 100 paraplégiques (prospectifs), 28 pour cent des organes rénaux ont empiré, mais seulement un organe de plus que la catégorie $\mathrm{n}^{\circ}$ I (la pyélonéphrite chronique). Trente-neuf pour cent des organes dont on avait détourné l'anse rénale ont empiré après dix ans. Bien que les résultats ne soient pas concluants, il paraît que les patients à qui on fait l'opération de l'anse iliaque subissent peut-être à long terme plus de lésions rénales. Donc, jusqu'à ce qu'on ait plus de données nous nous en tiendrons à une opinion réservée en recommandant l'urétéroiléostomie à ces patients.

\section{ZUSAMMENFASSUNG}

Eine Ureteroileostomie wird nur bei andauernder oder fortschreitender Hydronephrose nach Versagen herkömmlicher Behandlung der Blase in Betractht gezogen. Es wurde ein Versuch unternommen, diese Methode zu rechtfertigen, indem man den Nierenzustand von doppelseitig Gelähmten ohne solche Umleitung nach Io Jahren mit dem Io-jährigen Literaturüberblick über Ureterileostomie verglich, die bei gutartigen Erkrankungen angelegt worden waren. Bei den IOO doppelseitig Gelähmten (vorausschauend) ergab sich ein Verschleissen von 28 per cent der Nierenanlagen, jedoch nur eine Anlage über Grad I, der chronischen Pyelonephritis. Neununddreissig Prozent der Ureterileostomieen verschlissen nach Io Jahren. Obgleich dies keinen endgültigen Schluss zulässt, scheint es doch, dass Patienten mit langzeitigen Ureteroileostomie mehr Nierenschaden erleiden. Bis weitere Untersuchungsergebnisse vorliegen bleiben wir deshalb vorsichtig beim Empfehlen von Ureteroileostomien für diese Patienten.

\section{REFERENCES}

Donnelly, J., HaCkler, R. H. \& Bunts, R. (I972). Present urologic status of the World War II paraplegic: 25-year follow-up. Comparison with status of the 20-year Korean War paraplegic and 5-year Vietnam paraplegic. F. Urol., 108, 558.

HACKLER, R. H. (1973). Spinal cord injuries: urologic care. Urology, 2, 13.

HACKLER, R. H. (I977). A 25-year prospective mortality study in the spinal cord injured patient: comparison with the long-term living paraplegic. F. Urol., 117, 486.

Hoffman, C. A., JR. \& BunTs, R. C. (I96I). Present urologic status of the World War II paraplegic: fifteen-year follow-up; comparison with status of five-year Korean War paraplegic. F. Urol., 16, 60.

HUTCH, J. A. (I957). The treatment of hydronephrosis by sacral rhizotomy in paraplegia. F. Urol., 77, 123 .

Hutch, J. A. \& BunTs, R. C. (I95I). The present urologic status of the war-time paraplegic. F. Urol., 66, 218.

KozIol, I. \& HACKLER, R. H. (1975). Cutaneous ureteroileostomy in the spinal cord injured patient: a I5-year experience. F. Urol., 114, 709 .

LORD, K. H. \& BUNTs, R. C. (I956). Present urologic status of the World War II paraplegic: ten year follow-up. f. Urol., 75, 66.

MANFREDI, R. H. \& LEAL, J. F. (I968). Selective sacral rhizotomy for the spastic bladder syndrome in patients with spinal cord injuries. F. Urol., 100, 17.

$16 / 3-\mathrm{C}$ 
Misak, S. J., Bunts, R. C., Ulmer, J. L. \& Eagles, W. M. (I962). Nerve interruption procedures in the urologic management of paraplegic patients. F. Urol., 88, 392.

Rockswold, G. L., Bradley, W. E. \& ChOU, S. N. (1973). Differential sacral rhizotomy in the treatment of neurogenic bladder dysfunction. Preliminary report of 6 cases f. Neurosurg., 33, 748.

Wadewitz, P., Langlois, P. J. \& Bunts, R. C. (1968). Present urologic status of the World War II paraplegic: 20-year follow-up. Comparison with status of the I0-year Korean War paraplegic. f. Urol., 98, 706. 